\title{
Feeding Ecology of Feral Horses in Western Alberta
}

\author{
R.E. SALTER AND R.J. HUDSON
}

\begin{abstract}
Foraging behaviour and diets of feral horses were studied throughout one annual cycle in western Alberta. The availability of preferred forage plants appeared to be a primary determinant of habitat utilization during all seasons. Horses spent about $75 \%$ of daylight hours foraging during winter and spring with an apparent decrease in feeding time in summer. They were adept at obtaining forage from beneath snow. Fecal fragments analysis showed that gramineous plants were the major dietary constituents, never falling below a level of $83 \%$ in monthly diets. Sedges (Carex spp.), hairy wild rye (Elymus innovatus) and fescues (Festuca spp.) were the most important food plants. A fecal index technique suggested strong seasonal variation in diet quality.
\end{abstract}

Horses are primarily grazers (Hafez et al. 1969), but until the recent interest in feral horses little else was known of their foraging behaviour or food preferences on natural range. Several studies have shown that horses spend the majority of their time foraging (Tyler 1972; Feist and McCullough 1976; Berger 1977) and niay graze some areas repeatedly while others remain untouched (Odberg and Francis-Smith 1976, 1977). Grasses and sedges are the primary forages chosen (Hansen 1976; Hubbard and Hansen 1976; Hansen and Clark 1977; Hansen et al. 1977; Olsen and Hansen 1977). Although horses are able to utilize low quality forages (Slade et al. 1970) and are exceptionally hardy in cold climates (Andreyev 1971; Dieterich and Holleman 1973), environmental and nutritional stresses may sometimes result in widespread starvation (Dieterich and Holleman 1973; Welsh 1975). Objectives of the present study were to determine the annual diet composition of a population of feral horses in the ioothills of western Alberta, and to examine behavioural adaptations of horses for foraging in this seasonally severe environment.

\section{Study Area}

The study areas encompassed approximately $200 \mathrm{~km}^{2}$ of the outer foothills of the Rocky Mountains, west-southwest of Sundre, Alta. The area was within the Upper Foothills section of the Boreal Forest as defined by Rowe (1972). Elevation varied from 1,300 to 1,900 m. A series of roughly parallel, forested ridges oriented along a NW-SE axis were the predominant topographical feature. Drainage was through numerous permanent streams.

The authors are graduate student and associate protessor. Department of Animal Science. University of Aloerta. Edmonton T6G 2E3

Financial support for this study was provided by the Forest Development Research Trust Fund. Alberta Forest Service.

Manuscript received May 8.1978.
Forest cover consisted largely of lodgepole pine (Pinus contorta) with smaller stands of white spruce (Picea glauca), black spruce $(P$. mariana), alpine fir (Abies lasiocarpa), aspen (Populus tremuloides), and balsam poplar ( $P$. balsamifera). Mixed woods formed a major forest component. Meadow vegetation types on a moisture gradient from flooded to dry comprised the nonforested cover. Sedge and low shrub fens with smooth to hummocky microtopography were characteristic of mesic conditions, such as occurred in flat or gently sloping valley bottoms. Associations dominated by bearded wheatgrass (Agropyron subsecundum), Junegrass (Koeleria cristata), and intermediate oatgrass (Danthonia intermedia) were developed on southfacing slopes and in gently rolling meadows. Meadow and scrub vegetation covered approximately $20 \%$ of the study area.

Daily minimum temperatures average above $0^{\circ} \mathrm{C}$ only during JuneAugust in this region. Extreme maximum temperatures of $32^{\circ} \mathrm{C}$ have been recorded during August and September, while extreme minimum temperatures of $-42{ }^{\circ} \mathrm{C}$ have occurred during December (Environment Canada 1973a). Mild spells accompanied by warn west winds (Chinooks) are a prominent feature of the winter climate. March and April are the months of peak snowfall, averaging 49 and $48 \mathrm{~cm}$ respectively, although the monthly mean is between 12 and $21 \mathrm{~cm}$ throughout the period September-May (Environment Canada 1973b).

Over 200 feral horses were present on the area during the study.

\section{Methods}

All or part of 205 days were spent on the study area in 1976 (11 to 24 days each month); information on feeding behaviour was obtained primarily during 298 hours of observation of horse herds within this period. Examination of feeding areas and salt licks throughout the ycar provided supplementary data.

Records of the number of animals engaged in specific, undisturbed activities were obtained by scan sampling (Altmann 1974) at regular intervals during 99 of the 298 hours of observation to obtain guantitative information on activity cycles in relation to time of day and season of year. Records were maintained at 15-min intervals during 25 hours and at 5-min intervals during 74 hours. These were summed on an hourly basis for the periods January-March and April-June, inclusive. Time spent feeding and resting was calculated as the percent of animals recorded in each activity. Activities such as walking, agonistic interactions, play, and grooming were noted in the field but were tabulated in the category Other for purpose of this analysis. In addition, individual horses foraging in various snow depths were watched for thirty-six 5-min periods to determine the frequency of pawing bouts and the number of strokes per bout.

Diet composition was determined by identification of plant fragments in the feces. Fifty samples of fresh horse feces were collected during the last 3 weeks of each month in 1976, each sample consisting of one or two pellets. All samples were obtained within two areas (total 
30 ha) utilized for quantitative assessment of habitat utilization. An attempt was made to collect horse feces from several sites during each month, and not more than 15 samples were obtained from any one site. Individual fecal samples were combined on an approximately equal dry weight basis into 12 composite samples representing monthly diets. Approximately $10 \mathrm{~g}$ of each thoroughly mixed composite sample were sent to the Composition Analysis Laboratory, Colorado State University, for analysis (Hansen et al. n.d.; Sparks and Malechek 1968). This technique provides results which approximate the relative dry weights of food categories in the diet (Hansen et al. 1973; Todd and Hansen 1973; Dearden et al. 1975).

Seasonal changes in diet quality were estimated indirectly through fecal analysis. Crude protein and acid detergent fibre levels in each of the 12 monthly fecal samples wcre determined by the Agricultural Soil and Feed Testing Laboratory, Alberta Department of Agriculture.

\section{Results}

\section{Feeding Behaviour}

Horses utilized virtually all habitat types for foraging, although seasonal use varied. Forage availability appeared to be a primary determinant of habitat selection during winter, and only habitats limited in aeral extent or with sparse forage growth were clearly underutilized. Habitat occupancy during spring was related to stage of forage growth; previously grazed meadows and disturbed areas were the first to green-up and were heavily used for fceding. This resulted in localized damage to vegetation from close cropping and trampling. Horses also fed under forest cover during spring; the pattern of use of both forested and meadiow habitats for feeding continued through summer, fall, and early winter.

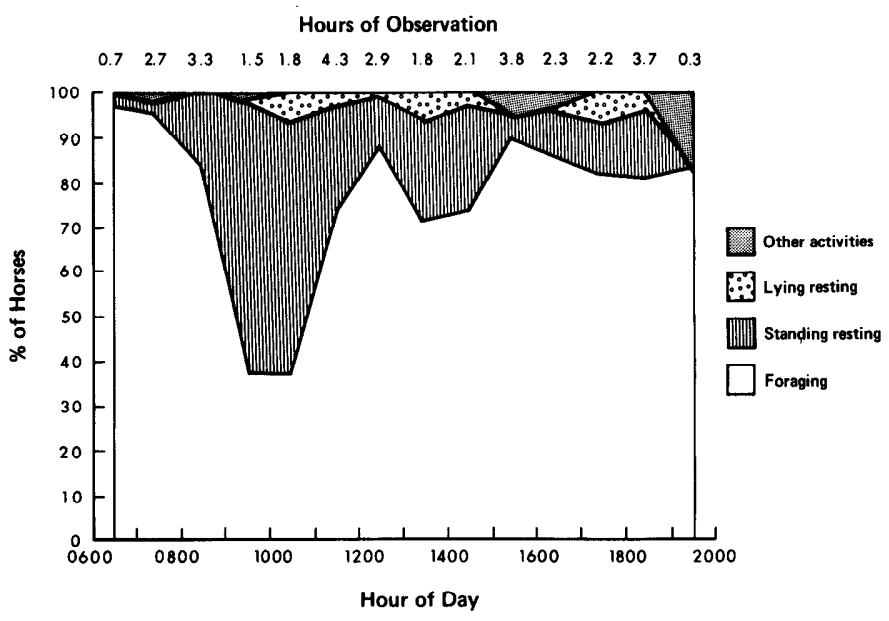

Fig. 1. Activity patterns of horses during daylight hours, January-March, 1976.

About three-quarters of daylight hours were spent foraging during winter (Fig. 1). Yearling and older horses continued to spend nearly $75 \%$ of daylight hours feeding in spring (Fig. 2), and except for a 2-hour lull in mid-morning, feeding activities predominated from dawn to dusk during both seasons. Foals spent an average $41 \%$ of their time foraging, $13 \%$ standing resting, 26\% lying resting, $4 \%$ suckling, and $15 \%$ in other activities. Limited observations suggested that foraging by yearling and older horses continued throughout the night during all seasons, but with a decrease in diurnal feeding time (at least in open areas) during summer and fall.

\section{Foraging in Snow}

During winter, horses pawed away the overlying snow to expose food plants. Although observed at all snow depths,
Hours of Observation

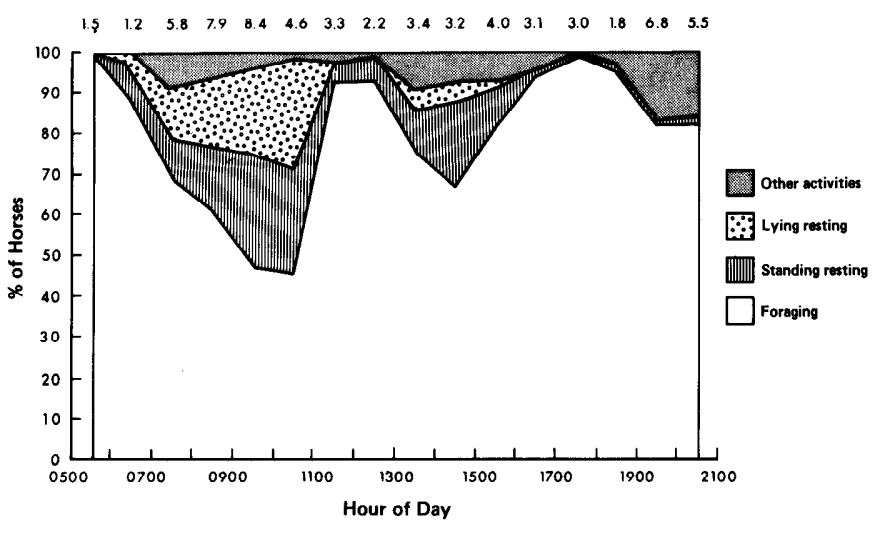

Fig. 2. Activity patterns of horses (exclusive of foals) during daylight hours. April-June, 1976.

pawing was resorted to more frequently in deep as compared to shallow snow cover, and cach pawing bout tended to involve more strokes (Table 1). Up to 19 strokes per bout were used in deep snow cover. The animals appeared well able to cope with the snow depths encountered on the study area during January March, and craters were found in snow as deep as $60 \mathrm{~cm}$.

Table 1. Frequency of pawing by foraging horses in relation to snow depth.

\begin{tabular}{cccc}
\hline $\begin{array}{c}\text { Snow depth } \\
(\mathrm{cm})\end{array}$ & $\begin{array}{c}\text { Number of 5-min } \\
\text { observations }\end{array}$ & $\begin{array}{c}\text { Mean number of } \\
\text { pawing bouts/ } \\
5 \text { min } \pm 1 \text { s.d. }\end{array}$ & $\begin{array}{c}\text { Mean number of } \\
\text { strokes/pawing } \\
\text { bout } \pm 1 \text { s.d. }\end{array}$ \\
\hline 10 & 16 & $1.4 \pm 2.0$ & $5.4 \pm 1.8$ \\
$40-50$ & 9 & $9.1 \pm 3.8$ & $9.7 \pm 3.6$ \\
\hline
\end{tabular}

Horses also were able to feed in shallow snow without pawing. In these situations snow was 'plowed' away by pushing the muzzle through the snow at a selected spot, and subsequent snow clcaring was accomplished by thrusting the muzzle forward while feeding. It appeared that this technique also was used to enlarge or clear snow from craters already created by pawing; it was used without pawing only at the shallowest snow depths (Table 2).

Table 2. Number of herd sightings during which pawing was used by foraging horses in relation to snow depth.

\begin{tabular}{lcccccc}
\hline \hline $\begin{array}{l}\text { Number of } \\
\text { observations } \\
\text { involving: }\end{array}$ & \multicolumn{6}{c}{ Snow depth (cm) } \\
\cline { 2 - 7 } & $1-10$ & $11-20$ & $21-30$ & $31-40$ & $40+$ & Total \\
\hline Pawing & 10 & 7 & 4 & 5 & 2 & 28 \\
No pawing & 6 & 2 & 0 & 0 & 0 & 8 \\
\hline
\end{tabular}

In addition to these behavioural adaptations for feeding in snow, horses took advantage of reduced snow depths at tree bases in woods, and on hummocks and around shrub bases in open areas. Steep south-facing slopes remained snow-free or had reduced snow depth throughout the winter and also were exploited as feeding hahitat. However, bare areas were not always favoured as evidenced by observations of horses feeding in isolated snow patches.

\section{Drinking}

Horses were seen drinking on only seven occasions. Water was readily available from the numerous streams in the study 
area, and consequently horses did not gather at specific sites to drink as reported ior more arid areas (Feist and McCullough 1976; Berger 1977). Water requirements in winter were probably met largely by ingestion of snow.

\section{Use of Salt Licks}

Horses ingested quantities of soil at both natural mineral licks and cattle salt licks throughout much of the year. Chemical analyses of soil, feces, and vegetation indicated that soil-eating likely was related to $\mathrm{Na}$ deficiency (Salter and Pluth in prep.).
Diet Composition

The annual diet was comprised of up to 43 plant categories (species and species groups). From 17 to 21 of these were found in each monthly diet (Table 3). Grasses, sedges, and rushes constituted the bulk of the diet throughout the year. Within this group grasses were most important. Hairy wildrye was utilized throughout the year, constituting on average over $25 \%$ of the monthly diet with a decrease in utilization, probably related to increased availability of more palatable forage, during MayJuly. Fescues (likely most F. scabrella) averaged $20 \%$ of the

Table 3. Percentages of plant fragments in feces of feral horses, 1976.

\begin{tabular}{|c|c|c|c|c|c|c|}
\hline Species & Jan.-Mar. & Apr.-May & June-Aug. & Sept.-Oct. & Nov.-Dec. & Annual \\
\hline \multicolumn{7}{|l|}{ Grasses } \\
\hline Agrostis scabra (hairgrass) & 0.1 & 0.7 & 0.5 & 1.3 & 0.4 & 0.5 \\
\hline Agropyron spp. (wheatgrass) & 0.2 & 0.1 & 0.2 & 0.0 & 0.1 & 0.1 \\
\hline Bromus spp. (bromegrass) & 0.1 & 0.0 & 0.3 & 0.5 & 0.1 & 0.2 \\
\hline Calamagrostis spp. (reedgrass) & 0.2 & 0.1 & 0.1 & 0.3 & 0.0 & 0.1 \\
\hline Danthonia inermedia (timber oatgrass) & 0.6 & 2.4 & 2.3 & 3.0 & 1.6 & 1.9 \\
\hline Deschampsia caespitosa (tufted hairgrass) & 0.8 & 1.1 & 1.4 & 1.6 & 1.7 & 1.3 \\
\hline Elymus innovatus (hairy wildrye) & 27.5 & 18.3 & 21.1 & 32.0 & 37.7 & 26.8 \\
\hline Festuca spp. (fescue) & 15.2 & 22.1 & 24.1 & 22.5 & 19.0 & 20.4 \\
\hline Glyceria spp. (mannagrass) & 0.0 & 0.0 & 0.0 & 0.0 & 0.0 & $\mathrm{~T}$ \\
\hline Helictotrichon hookeri (hooker's oatgrass) & 0.0 & 0.1 & 0.0 & 0.0 & 0.0 & $\mathrm{~T}$ \\
\hline Koeleria cristata (Junegrass) & 1.0 & 1.0 & 0.0 & 1.5 & 2.5 & 1.1 \\
\hline Muhlenbergia spp. (muhly grass) & 0.0 & 0.0 & 0.1 & 0.0 & 0.0 & $\mathrm{~T}$ \\
\hline Phleum spp. (bluegrass) & 0.0 & 0.0 & 0.0 & 0.0 & 0.0 & $\mathrm{~T}$ \\
\hline Poa spp. (bluegrass) & 0.6 & 2.3 & 2.6 & 5.2 & 0.8 & 2.2 \\
\hline Schizachne purpurascens (false melic) & 1.7 & 1.2 & 0.3 & 0.9 & 0.1 & 1.0 \\
\hline Stipa spp. (needlegrass) & 0.0 & 0.7 & 0.1 & 1.6 & 0.3 & 0.4 \\
\hline Tristeum spicatum (spike trisetum) & 0.1 & 0.0 & 0.0 & 0.0 & 0.0 & $\mathbf{T}$ \\
\hline Total grasses & 48.2 & 49.9 & 53.1 & 70.0 & 64.9 & 56.1 \\
\hline \multicolumn{7}{|l|}{ Sedges and Rushes } \\
\hline (arex spp. (sedge) & 35.2 & 42.4 & 41.1 & 24.0 & 22.6 & 33.9 \\
\hline Eriophorum viridi-carinatum (cotton grass) & 0.4 & 0.1 & 2.0 & 0.4 & 0.0 & 0.7 \\
\hline Juncus balticus (wire rush) & 3.7 & 0.0 & 2.3 & 0.9 & 2.0 & 1.9 \\
\hline Scirpus caespitosus & 0.0 & 0.0 & 0.0 & 0.0 & 0.0 & $\overline{\mathrm{T}}$ \\
\hline Total sedges and rushes & 39.3 & 42.6 & 45.3 & 25.2 & 24.5 & 36.5 \\
\hline Total grasses, sedges and rushes & 87.5 & 92.5 & 98.5 & 95.2 & 89.3 & 92.6 \\
\hline \multicolumn{7}{|l|}{ Forbs } \\
\hline Artemisia spp. (sagewort) & 0.0 & 0.0 & 0.0 & 0.0 & 0.1 & $\mathrm{~T}$ \\
\hline Astragalus frigidus (milk vetch) & 0.0 & 0.0 & 0.0 & 0.7 & 0.1 & 0.1 \\
\hline Mertensia paniculata (tall mertensia) & 0.0 & 0.0 & 0.0 & 0.0 & 0.0 & $\mathrm{~T}$ \\
\hline Petasites spp. (sweet coltsfoot) & 0.0 & 0.0 & 0.0 & 0.0 & 0.1 & $\mathrm{~T}$ \\
\hline Potentilla-Geum spp. (cinquefoil-avens) & 0.3 & 0.6 & 0.3 & 0.3 & 0.2 & 0.3 \\
\hline Solidago spp. (goldenrod) & 0.0 & 0.0 & 0.0 & 0.0 & 0.1 & $\mathrm{~T}$ \\
\hline Stellaria spp. (chickweed) & 0.0 & 0.0 & 0.1 & 0.0 & 0.0 & $\mathrm{~T}$ \\
\hline Vicia americana (wild vetch) & 0.1 & 0.0 & 0.0 & 0.4 & 0.0 & 0.1 \\
\hline Unidentified forbs & 0.2 & 0.3 & 0.2 & 0.5 & 0.0 & 0.2 \\
\hline Total forbs & 0.6 & 0.8 & 0.8 & 1.9 & 0.4 & 0.8 \\
\hline \multicolumn{7}{|l|}{ Browse } \\
\hline Picea spp. (spruce) & 0.9 & 0.2 & 0.0 & 0.0 & 0.3 & 0.3 \\
\hline Pinus contorta (lodgepole pine) & 4.7 & 2.0 & 0.1 & 1.4 & 4.9 & 2.6 \\
\hline Populus spp. (poplar) & 0.2 & 0.0 & 0.0 & 0.0 & 0.0 & $\mathrm{~T}$ \\
\hline Sulix spp. (willow) & 0.1 & 0.4 & 0.0 & 0.0 & 0.0 & 0.1 \\
\hline $\begin{array}{l}\text { Shepherdia canadensis-Elaeagnus com- } \\
\text { mutata (Canadian buffaloberry-silveryberry) }\end{array}$ & 0.0 & 0.5 & 0.2 & 0.1 & 0.0 & 0.2 \\
\hline Total browse & 5.9 & 3.0 & 2.3 & 1.5 & 5.1 & 3.6 \\
\hline \multicolumn{7}{|l|}{ Miscellaneous } \\
\hline Equisetum spp. (horsetail) & 2.6 & 1.4 & 0.3 & 0.5 & 3.5 & 1.6 \\
\hline Lichen & 0.0 & 0.0 & 0.0 & 0.2 & 0.1 & $\mathrm{~T}$ \\
\hline Moss & 3.3 & 2.5 & 0.1 & 0.8 & 1.4 & 1.6 \\
\hline Total miscellaneous & 5.9 & 3.8 & 0.4 & 1.5 & 4.9 & 3.3 \\
\hline
\end{tabular}


diet. No other grass constituted more than a mean of $2.2 \%$ of the monthly diet although several approximated or surpassed this figure during one or more months. Sedges were important throughout the year, ranging between $18 \%$ (September) and $56 \%$ (May) of diet composition. Wire rush (Juncus balticus) was consistently present but averaged less than $2 \%$ of the monthly diet, as did horsetails (Equisetum spp.).

Forbs were utilized very little by horses and were found at a total level of less than $3 \%$ during each month. Species in the Potentilla-Geum group were the only ones that appeared consistently.

Browse was a highly variable dietary constituent, ranging from $0 \%$ in June to $9 \%$ in March. Although willows (Salix spp.), poplar, and buffaloberry (Shepherdia canadensis) (or possibly silverberry (Elaeagnus commutata), were all identified, none reach a level of $1 \%$ during any one month and all were inconsistent in occurrence. In contrast, lodgepole pine needles and to a lesser extent spruce needles were consistently found in the feces; both were absent only during May and June.

\section{Diet Quality}

Fecal crude protein and acid detergent fibre levels showed strong seasonal variation (Fig. 3). Assuming that low values of fecal crude protein and high fibre levels indicate a poor quality diet, and that the opposite situation indicates a relatively higher quality diet, the curves in Figure 3 reflect the growth stage of forages selected. During winter only weathered forages were available. Greenup began in March (first noted March 13) and the increasing availability of new growth was reflected in a rapid rise in diet quality between April and May, with a peak in June. Diet quality declined steadily thereafter as forages matured, cured, and began to weather.

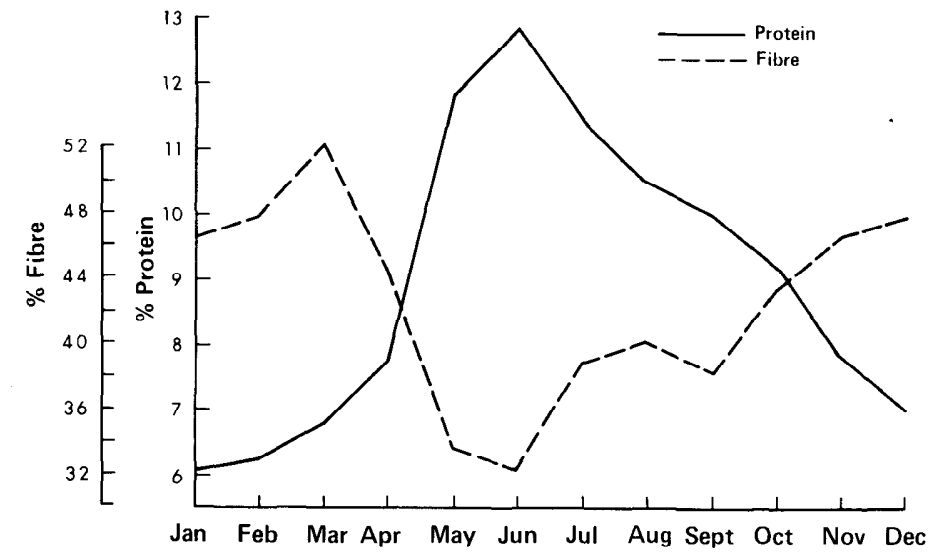

Fig. 3. Monthly variation in levels of crude protein and acid detergent fibre (\%DM) in composite samples of horse feces, 1976

\section{Discussion}

The predominance of grasses and sedges in the diet of feral horses in the Alberta foothills is consistent with reports from other areas. Grasses and sedges together constituted from $50 \%$ to over $90 \%$ of annual diets of feral horses in the western United States (Hansen 1976; Olsen and Hansen 1977), although the relative importance of each group varied with local availability. In the U.S.S.R., under conditions more comparable to the Alberta foothills, grasses and sedges were considered to bc among the best piants for winter feeding (Andreyev 1971).

In the present study, the importance of individual species in the annual diet and seasonal shifts in diet composition likely were related to both palatability and availability factors. Thus, although hairy wildrye is considered to be unpalatable at all seasons (Campbeli et al. 1966), it was widely available and formed an important constituent of the annual diet. Fescues and sedges, the other major dietary constituents, are both considered valuable forages (Campbell et al. 1966; Hermann 1970) and were widespread within the study area. Browse plants and forbs also were widely distributed but were little used by horses. Because no evidence of browsing on living conifers was found at any time during the study, it seems most likely that material in the feces represented fallen needles ingested accidentally while grazing other forage. This hypothesis is strengthened by the fact that levels were highest during the winter months when snow cover presumably decreased the ability of the horses to graze selectively. Mosses and lichens present in the feces may have been ingested under similar circumstances.

Fecal protein and fibre levels were used in this study to infer seasonal trends in diet quality, following Hebert (1973), who showed a positive correlation between fecal protein and quality of forages ingested by bighorn sheep (Ovis canadensis), and Gates (1975) and McFetridge (1977), who interpreted variation in fecal crude protein as indicating seasonal shifts in vegetation quality on bighorn sheep and mountain goat (Oreamnos ameri(canlis) ranges, respectively. Klein (1962) suggested a negative correlation between fibre content in the feces and the quality of range used by blacktailed deer (Odocoileus heminonus columbiamus). Major forages in the Alberta foothills are highest in crude protein and lowest in fibre during spring, but reach a low quality during winter (Johnston and Bezeau 1962). As expected, quality of diet ingested by horses followed this trend. Horses selected new growth on previously grazed areas in spring - and to some extent throughout the growing season-and may thus have effectively prolonged the period of availability of high quality forage. Ungrazed areas were utilized primarily during the period of snow cover.

Horses can survive even subarctic conditions if forage of sufficient quality is available (Andreyev 1971; Dieterich and Holleman 1973). They are adept at obtaining forage from beneath snow and can successfully utilize low quality feeds (Slade et al. 1970), but nevertheless experience weight loss when maintained on native range over winter (Dawson et al. 19+5; Andreyev 1971). Nutritionally stressed animals are predisposed to starvation under deep snow and severe weather conditions (Dieterich and Holleman 1973; Welsh 1975), and large die-offs have been documented along the Alberta foothills and in interior British Columbia by Forest Service personnel. However, in the absence of long-term data the importance of nutritional stress in regulating population levels cannot be determined.

\section{Literature Cited}

Altmann, J. 1974. Observational study of behaviour: sampling methods. Behaviour 49:227-267.

Andreyev, V.N. 1971. Horse herding for meat in Yakutskaya ASSR. Polar Record 15:931-933.

Berger, J. 1977. Organizational systems and dominance in feral horses in the Grand Canyon. Behav. Ecol. and Sociohiol. 2:131-146.

Campbell, J.B., K.F. Best, and A.C. Budd. 1966. Ninety-nine range forage plants of the Canadian prairies. Canada Dep. Agr. Pub. 964, Ottawa. 102 p.

Dawson, W.M., R.W. Phillips, and S.R. Speelman. 1945. Growth of horses under western range conditions. J. Anim. Sci. 4:47-54.

Dearden, B.L., R.E. Pegau, and R.M. Hansen. 1975. Precision of microhistological estimates of ruminant food habits. J. Wildl. Manage. 39:402 407.

Dieterich, R.A., and D.F. Holleman. 1973. Hematology, biochemistry, and physiology of environmentally stressed horses. Can. J. Zool. 51:867-873.

Environment Canada. 1973(a). Canadian normals. Vol. 1: Temperature, 1941-1970. Environment Canada, Atmospheric Environment. 
Environment Canada. 1973(b). Canadian normals. Vol. 2: Precipitation, 1941-1970. Environment Canada, Atmospheric Environment.

Feist, J.D., and D.R. McCullough. 1976. Behavior patterns and communication in feral horses. Z. Tierpsychol. 41:337-371.

Gates, C.C. 1975. Aspects of the environment-lungworm bighorn sheep (Ovis c. canadensis) system. M.Sc. Thesis. Univ. of Alberta. 55 p.

Hafez, E.S.E., M. Williams, and S. Wierzbowski. 1969. The behaviour of horses. p 391-416, In: E.S.E. Hafez (ed.). The Behaviour of Domestic Animals. Balliere, Tindall and Cassell, London.

Hansen, R.M. 1976. Foods of free roaming horses in southern New Mexico. J. Range. Manage. 29:347.

Hansen, R.M., and R.C. Clark. 1977. Foods of elk and other ungulates at low elevations in northwestern Colorado. J. Wildl. Manage. 41:76-80.

Hansen, R.M., R.C. Clark, and W. Lawhorn. 1977. Foods of wild horses, deer, and cattle in the Douglas Mountain area, Colorado. J. Range Manage. 30:116-118.

Hansen, R.M., T.M. Foppe, M.B. Gilbert, R.C. Clark, and H.W. Reynolds. n.d. The microhistological analysis of feces as an cstimator of herbivore dietary. Unpublished MS, Composition Analysis Lab., Colorado State Univ. Fort Collins. 20 p.

Hansen, R.M., D.G. Peden, and R.W. Rice. 1973. Discerned fragments in feces indicate dietary overlap. J. Range Manage. 26:103-105.

Hebert, D.M. 1973. Altitudinal migration as a factor in the nutrition of bighorn sheep. PhD Thesis. Univ. of British Columbia. $357 \mathrm{p}$.

Hermann, F.J. 1970. Manual of the Carices of the Rocky Mountains and Colorado Basin. Agr. Handbook No. 374. Forest Serv. U.S. Dep. Agr. U.S. Gov't. Printing Office, Washington, D.C. 397 p.

Huhbard, R.E., and R.M. Hansen. 1976. Diets of wild horses, cattle, and mule deer in the Piceance Basin, Colorado. J. Range Manage. 29:389-392. Johnston, A., and L.M. Bezeau. 1962. Chemical composition of range forage plants of the Festuca scabrella association. Can. J. Plant Sci. 42:105-115. 115.
Klein, D.R. 1962. Rumen contents analysis as an index to range quality. Trans. N. Amer. Wildl. Conf. 27:150-164.

McFetridge, R.J. 1977. Strategy of resource use by mountain goats in Alberta M.Sc. Thesis. Univ. of Alberta. 148 p.

Odberg, F.O., and K. Francis-Smith. 1976. A study of eliminative and grazing behaviour - the use of the field by captive horses. Equine Vet. J. 8: 147-149.

Odberg, F.O., and K. Francis-Smith. 1977. Studies on the formation of ungrazed eliminative areas in fields used by horses. Appl. Anim. Ethol. 3:27-34.

Olsen, F.W., and K.M. Hansen. 1977. Food relations of wild free-roaming horses to livestock and big game, Red Desert, Wyoming. J. Range Manage. 30:17-20.

Rowe, J.S. 1972. Forest regions of Canada. Can. Forest Serv. Pub. 1300. 172 p.

Salter, R.E., and D.J. Pluth. Determinants of mineral lick utilization by feral horses (submitted for publication).

Slade, L.M., D.W. Robinson, and K.E. Casey. 1970. Nitrogen metabolism in nonruminant herbivores. I. The influence of nonprotein nitrogen and protein quality on the nitrogen retention of adult mares. J. Anim. Sci. 30: $753-760$.

Sparks, D.R., and J.C. Malechek. 1968. Estimating percentage dry weight in diets using a microscope technique. J. Range Manage. 21:264-265.

Todd, J.W., and R.M. Hansen. 1973. Plant fragments in the feces of bighorns as indicators of food habits. J. Wildl. Manage. 37:363-366.

Tyler, S.J. 1972. The behaviour and social organization of the New Forest ponies. Anim. Behav. Monogr. 5:85-196.

Welsh, D.A. 1975. Population, hehavioural and grazing ecology of the horses of Sable Island, Nova Scotia. PhD Thesis, Dalhousie Univ. 403. p.

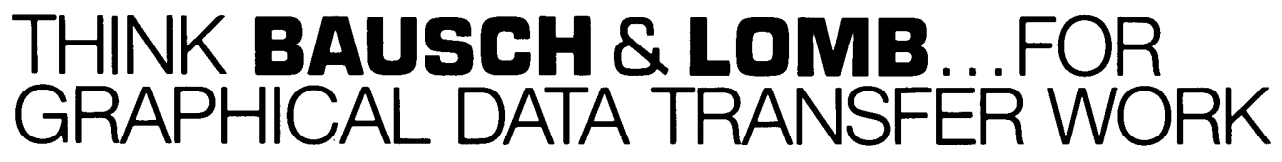

With a Bausch \& Lomb ZOOM TRANSFER SCOPE* instrument, you can quickly update a data base or prepare a special purpose thematic map without expensive data transfer, projection or darkroom equipment. These instruments work on the camera lucida principle that optically mix aerial photographs and data base without projection. Compare these performance features with what you are now using.

- Built-in scale and stretch correction systems compensate for photographic distortions. - Compact, lightweight design offers total portability. Can be used in a lighted office on any flat surface.

- Zoom control instantly matches photograph to data base scale.

- Accommodates all photographic formats including transparencies and prints (black and white or color). Stereo model (illustrated) helps you examine topographical and structural features. - Two models feature a photographic mode for permanent documentation.

\section{CALL US AT 716 338-6000}

And let a Bausch \& Lomb representative recommend the instrument that best meets your needs. Or, send coupon for illustrated literature.

*ZOOM TRANSFER SCOPE and Z.T.S. are trademarks of Bausch \& Lomb Incorporated for graphical data transfer instruments.
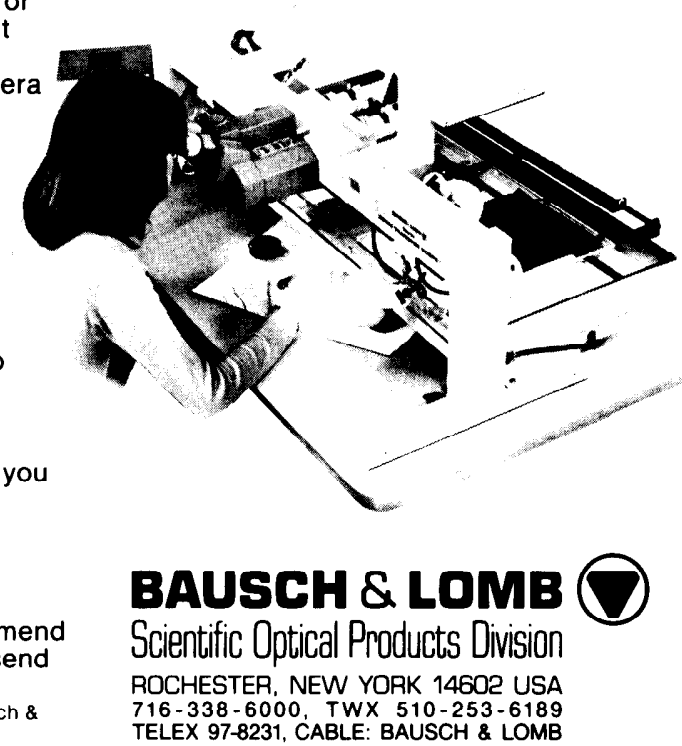

In Canada: Bausch \& Lomb Canada, Ltd. Scientific Optical Products Division, 2001 Leslie Street, Don Mills, Ontario, Canada M3B 2MS

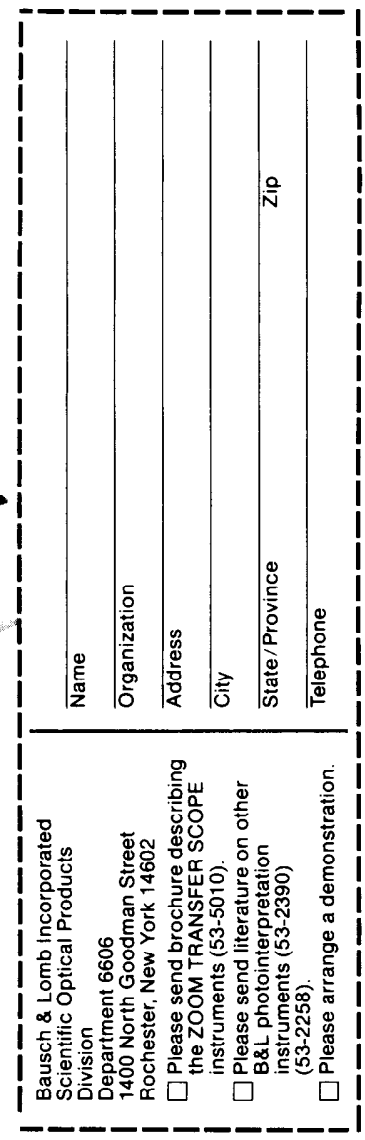

